УДК 821.163.41.09 Кочић, П. https://doi.org/10.18485/msc50.2019.1.ch51

\author{
Светозар Кољевић
}

\title{
ПАРОДИЈСКИ ОБЛИЦИ ЕПСКЕ НАРАЦИЈЕ У ПРИПОВЕТКАМА ПЕТРА КОЧИТА
}

Одјек усмене епске речи у делима оних писаца српскохрватског језика који су помицали његове изражајне границе суштаствен је колико и разнолик. Његош, рецимо, пева метафизичку драму смрти епског света у којој главни јунак види себе као беспомоћну „сламку међу вихорове”, а морална природа јуначког потхвата се објашњава космичким противречјима. Мажуранић, с друге стране, преображава крваве епске сукобе у камене ритуале језика и стила високо класицистички образованог човека. Домановић и Кочић већ откривају пародијске могућности усменог епског наслеђа у сликању епског фантазирања као комичког националног обележја, али док Домановићево откриће креће путевима сатиричне слике савремене Србије, дотле Кочићево стреми у сасвим другом, парадоксалном правцу. Јер циклус приповетки о Симеуну Ђаку није, као Смрт Смаил-аге Ченгића, чудесно рафинисана апотеоза усмене епске речи; нити је пак, као Горски вијенач, ерозија епског духа путем дугих рефлексивних монолога и „глобалних метафора”, односно повремених сатиричких, млетачких дигресија. Ни Симеун Ђак, ни епска традиција која се у казивању о њему богато користи, нису, у крајњој линији, предмет подсмеха или средства за шибање порока, него гротескно озарена визија потресне људске судбине у „пошљедњем времену” аустријске „укопације”.

Стога се и поређење с Дон Кихотом, још од Исидоре Секулић и Јована Дучића, многима наметало: без обзира што је у том упоређењу наш Симеун Ђак тек зрнце уметности, непресадива локална бољка, он је занимљив у суштини на дубоко аналоган начин. Као што Сервантес исмева облике испољавања средњовековног витешког духа величајући његове суштинске идеале, тако и Кочићево исмевање казанских манифестација наше комичне, или трагичне, склоности ка епском фантазирању представља у исти мах крајњу људску и имагинативну потврду ду- 
ховних и етичких простора нашег епског наслеђа. Пародија, укратко, не иде у правцу сатире, него креће ка парадоксу; а та удвојеност песничког гласа најјасније се види по томе што су све четири приповетке о Симеуну Ђаку, као, уосталом, и Дон Кихот, уоквирене приче, књижевни облик који свакако више подсећа на урбани менталитет, ни Овидија, Бокача, Чосера, Гета или Андрића, него на исказ усменог епског барда.

Тај оквир је у знаку епске дестилизације у све чтири приче: умјесто да на почетку казивања јунаци „вино пију” у „бијелим дворима”, манастирска братија, и понеки њен прирепак, пече ракију под ведрим небом. Уместо епске сублимације у којој и обичне сељачке куће често постају „бијели двори”, а вино се пије можда управо зато што је ракија била обичнији сељачки напитак, Кочићева прича почиње, не у неким епским висинама и даљинама, него ту, на лицу места, уз казан, и то каткад и уз неки „прошверцовани” казан, јер кад игуман добије дозволу за печење ракије, његов духовни статус му омогућује да без опасности „премакне и један ред преко дозволе"2. Укратко, као да је већ сам оквир Кочићевих приповетки пародичног епског порекла, иако је „уоквиривање” пре карактеристика уметничке но усмене књижевности. Но не само да је тај оквир по свом пореклу и функцији двосмислен, него се та двосмисленост и даље продужава у подругљивом гласу иза каце који повремено прекида Симеуново епско фантазирање, односно Мићанову демистификацију тог фантазирања у Истинитом зулуму Симеуна Ђака.

Тако се у Кочићевом приповедању остварује један у основи двосмислен медијум у коме се реалност и фантазирање непрестано преплићу и прожимају. Међутим, већ и сама природа те оквирне реалности крајње је разнолика и проблематична. Каткад нам се печење ракије указује као каменчић неке јесење идиле, кад се „кукурузи перушају”, кад је „све сређено”', кад настаје, дакле, време за причу и причање. Но то идилично време је уједно и „пошљедње вријеме” аустријске окупације, кад манастирске овбе редом цркавају, кад се владике „шајцају... са швапским роспијама”

1 Такви су, на пример, „Бијели двори” Таше Николића, где се хајдуци окупљају пре него што крећу на свој осветнички задатак, у песми Шта освета чини В. С. Караџић, Сриске народне пјесме, III, приредио В. Недић, Београд, 1976, бр. 69, стихови 45, 66.

${ }^{2}$ П. Кочић, Зулум Симеуна Ђака, Циклус о Симеуну ђаку и друге приповијетке, приредио С. Кољевић, Веселин Маслеша, Сарајево, 1982, стр. 123. Сви цитати из циклуса о Симеуну Ђаку наведени су према овом издању.

${ }^{3}$ Нав. дело. 
по Бањој Луци ${ }^{4}$, кад је стално све слабије - „и берићет и ракија и људи”, кад Симеун пркоси том новом поретку истичући да њему не требају „царске мјере” и „каурске лумере” да би градирао ракију не, у тој оквирној причи не представљају се само питања о промашајима космоса и историје, него и проблеми у вези са Симеуном - зашто га не закалуђерише? Да ли стога што толико пије (што не би био уверљив разлог с обзиром на неке друге примере) или пак стога што је тако пргаве ћуди, као што се, уосталом, из његовог епског фантазирања лепо види? О човеку, наиме, без сваке сумње много говори и оно што он може сам о себи слагати! И најзад, ракијски оквир каткад постаје повод за химну ракији, као неку пародију пародије, за истицање да се без ракије „не мереш ни крстити ни запросити ни испросити, ни вјенчати ни са'ранити”, те се зато она „тако зорли штима и у нашој светој и православној Русији”. Тај исти двојни пародијски тон, ироничан колико и химничан, звони каткад чак и у гласу оног иза каце, рецимо кад на крају Мејдана Симеуна Ђака он изиђе из мрака, сиђе са пиједестала свог ругања, скине сокус, пољуби Симеуна у руку и пружи му чашу хладне ракије: „Ово сам ја цијелу вече за тебе 'ладио, делијо наш и бранитељу ове наше свете ћабе! Прими ову чашу, наздрави ми, опрости ми и благослови ме!"8 Остављајући по страни питање етимологије речи „ћаба”, која у овом контексту означава оно што Симеун иначе назива „Немањића светом задужбином”, тешко је рећи да ли је и колико је, а камоли како је подсмешљивац преображен у обожаваоца. Али у сваком случају, некакав преображај се одиграо и то не можда толико због уверљивости Симеуновог подвига колико под дејством етичке снаге његовог причања, а можда и ракије. Али ако су и поред тог дејства, као што подозревамо, остале неке границе до којих се том преображају може веровати, онда је и то само знак двојности тона и двосмислености Кочићевог приповедања. Та двојност и та двосмисленост се исто тако огледа и на крају последње приповетке овога циклуса, Ракијо, мајко!: кад Симеун, који је још поодавно отпевао своју оду „мученици”, истакнувши да њему није жао што ракија упропасти толики свет колико што тај „свијет... упропасти толику ракију” ${ }^{10}$ заврши своју

\footnotetext{
4 Мејдан Симеуна Бака, стр. 139.

5 Зулум Симеуна Бака, стр. 123.

${ }^{6}$ Истинити зулум Симеуна Бака, стр. 130.

7 Ракијо, мајко!, стр. 149.

8 Мејдан Симеуна Ђака, стр. 148.

9 Ракијо, мајко, стр. стр. 150 и др.

10 Нав. дело, стр. 158-159.
} 
дидактичку „Јуначино наша!” обратиће се он Симеуну, „Нека ти је просто и од бога и од људи, да је каблом пијеш, кад си је тако делијски и јуначки бранио и одбранио! Точи, Мићане!”1. Чак и у две последње стамено погођене речи - „Точи, Мићане!” - има, дакако, пуно шале, али у свакој, па и овој шали има бар пола збиље.

Поред овако богато изведене и разуђене оквирне приче, која је тек пореклом одјек једне карактеристичне формуле којом почињу многе јуначке десетерачке песме, овај Кочићев циклус садржи и оне „епске”, уоквирене приче у којима је неупоредиво гушће ткање алузија на наше усмено песништво и његове наративне шеме и шаблоне. Ту су, по правилу, припреме, укључујући ситне књиге и описе одеће, оружја и појаве јунака, затим поход, каткад и причешћивање уочи окршаја, те зачикавање противника и главни сукоб и, најзад, ликовање у победи. А све је то повремено проткано и карактеристичним епским прерушавањем главног јунака, гозбама, одметањем у хајдуке, понижавањем противника, као и низом алузија међу којима су свакако најзначајније, поред „Немањића славне задужбине", Косова и Краљевића Марка, оне које се односе на аустро-угарско „пошљедње вријеме” као комплекс цивилизације и „сувог зулума" ${ }^{\prime 2}$. Укратко, у уоквиреној причи, уобличеној на наративној схеми јуначке десетерачке песме, с бројним епским алузијама, честим преласком у десетерачки говор па и навођење познатих стихова, формална противтежа том епском акценту остварује се тако што јунак, с изузетком Мићанове приче о његовом „истинитом” зулуму, сам себе велича у ракијском заносу. И управо захваљујући тој техници која је страна епском духу бар утолико што је занос изразито ракијског порекла, пародија опет често долази до граница донкихотског парадокса.

Као што је вино у оквирној причи постало „ракија”, односно у свом разводњеном виду вотка (јер где би тек Русима крај био кад би пили нашу, праву ракију), тако и „ситне” или „танке књиге” у уоквиреној причи постају оне „депешине... лепешине”, које Партеније и Симеун примају из Београда и Црне Горе и због којих су, како нам каже Давид Штрбац, Турци кивни на њих двојицу ${ }^{13}$. Али, с друге стране, како опет каже Давид Штрбац, зуцка се да они примају „лепешине” и из Беча, те да су они у ствари „довели Швабу у Босну" ${ }^{14}$. И док Давид, омален и лукав сељак, тако, ето, свашта прича, он се у исти мах обраћа Симеуну као „јунаку и

\footnotetext{
11 Нав. дело, стр. 176.

12 Нав. дело, стр. 157, 165.

13 Истинити зулум Симеуна Бака, стр. 131.

14 Мејдан Симеуна Бака, стр. 145.
} 
бранитељу ове наше свете ћабе"15. И та мешавина подозрења и дивљења у ствари је веома карактеристична: довољно је, уосталом, сетити се ко је Давид Штрбац и каква је природа његовог гласа, па да се сместа пробуди неопходни читалачки опрез кад су у питању његове речи.

Па ни други епски елементи - на пример, описи одеће и оружја нису баш тако пародијски једноставни као што се на први поглед чине. Дакако, пародијска функција је ту: као што Марко има свој ћурак, свог Шарца и своју „тешку топузину”, тако се и Симеун појављује у својој „швапској шкрљачини” и „овинцирској”, „генералској кабаници”, коју је купио „од неког Прајза” у Задру, „злу не требало” 16 . Он јаше ата кога му је „покојни владика Прокопије, каже, поклонио за стотину жутије' дуката"17, а и његова пушка, пострагија, аналоган је део тог епског пејзажа. Међутим, и у овим описима се остварује необично пародијско двогласје: кад Симеун описује смешним језиком и речима своју комичну појаву, драмска иронија остварује се тако што он верује да ће му слушаоци поверовати да је он био страх и трепет за противнике, што он подразумева да је довољно нешто „бркљачити” па да аустријска војска извршава његове команде. Оно што у томе плени и није можда толико слика комичне чежње за јунаштвом колико наивност коју Симеун од својих слушалаца захтева и очекује. И када он с типичним епским асоцијацијама раног устајања, беле зоре и молитве уочи боја, описује како је навукао „човали чакшире” и припасао „сабљетину, по земљи се вуче” 18 , чини се заправо да он не зна шта говори. Јер тај опис нам не призива у сећање неког великог епског јунака него жгољавог Вукашина:

Што Момчилу таман сабља била,

Вукашину с' аршин земљом вуче ${ }^{19}$.

Али у свету „сувог зулума” у коме сувише људи зна шта хоће и како то хоће, човек који не зна шта говори постаје нека врста хероја.

И како се приближује главни окршај у овим уоквиреним Симеуновим причама, као и у оној Мићановој, епска обележја постају, по правилу, не само гушћа него и невероватнија. То се огледа већ и у Симеуновој узгредној напомени како је Партенија погодио једног Крајишника у пов-

${ }^{15}$ Нав. дело.

16 Зулум Симеуна Ђака, стр. 125; Мејдан Симеуна Ђака, стр. 143-144; Ракијо, мајко!, стр. 152.

17 Зулум Симеуна Ђака, стр. 125.

${ }_{18}$ Нав. дело, стр. 125.

19 Женидба краља Вукашина, В. С. Караџић, Српске народне пјесме, II, бр. 25, стихови 282-283. 
лачењу право у чело: „А ја зграби’ штуц, па посред сриједе оног мјеста ђе је Партенија згодио! Ено му гроба, нек ми не да лагати”20. А када Симеун зађе у својој причи у планину, он ће ако не баш да кликне, а оно макар да „загрокће” првим десетерцима који се јављају у овој приповетки: ${ }^{21}$

Медењаче, висока планино,

не 'раниш ли у себи јунака,

који би ми на мејдан изиш’о?22

У том часу чак и онај подсмешљивац иза каце прелази у десетерац: „Не чуј, вило, не преузми гласа”, и десетерци се често уплићу у прозно приповедање све до Симеуновог уласка у Бронзани Мајдан ${ }^{23}$. Тај улазак, међутим, који би одговарао мегдану или боју у епској песми, доноси понижавање становништва и „погубљење” Шаћира Пулца, те у том смислу представља анти-климакс у уоквиреној јуначкој причи, те је стога и дат искључиво у прози.

На сличан начин, иако можда нешто мање изразито, у оквирној причи у Истинитом зулуму Симеуна Ђака готово да и нема десетераца (с изузетком: „Симендашу! Пострагијо стара!)”24, као што их нема ни у Мићановом опису главног окршаја - пљачкања Брадарине ракије. Међутим, у припреми за тај „окршај”, за пљачку ракије у години када је шљива слабо понела, десетерци су чести и бројни. Прво, кад се Симеун тобоже одметне, односно кад „про'ода горе до млина, па се пред мрак врати”25, он има утисак да још није куцнуо прави час за хајдучки поход на ракију, односно, како он то каже с косовским асоцијацијама, да још није дошао земан „за крст часни крвцу проливати, за 'Ристову вјеру умријети”26. Другог дана, на растанку, после неколико полића, управо у часу када креће да се „одметне” на четрнаест дана, Симеун већ жалостиво пева:

Већ је крвца из земље проврела, Земан дош'о, ваља војевати ${ }^{27}$.

20 Зулум Симеуна Бака, стр. 124.

${ }^{21}$ Нав. дело, стр. 126. Једини ранији пример десетерца у причи је заправо споран: „онда припаса сабљетину, по земљи се вуче”, стр. 125.

22 Женидба крала Вукашина, В. С. Караџић, Српске народне пјесме, II, бр. 25, стихови 282-283.

23 Зулум Симеуна Бака, стр. 126.

24 Истинити зулум Симеуна Бака, стр. 131.

25 Нав. дело, стр. 132.

${ }^{26}$ Нав. дело.

27 Нав. дело. 
Па и кад Симеун крене, тобож гонећи Партенију као одметник, у пљачку ракије, Партенија ће му саветовати да своју „ћурчину” „наизврат обуче"28 као што је обично чинио Краљевић Марко кад се наљути. Па и кад Симеун крене у ову лажну потеру и, у заносу, заправе припуца за Партенијом, он ће кликнути: „Стан’ курвићу, црни калуђере, данас мени измакнути нећеш"29. Али у средишњем призору - приликом пљачке ракије, комичког обреда венчавања Брадаре с котлом, те заједничког пијења ракије и помирења - ни десетераца ни епских асоцијација нема, тако да тај призор опет има сва обележја антиклимакса.

И у Мејдану Симеуна Ђака први и једини десетерац у оквирној, „ракијској” причи јавља се тек кад се помене предстојећи Симеунов мегдан с Асан-бегом Чеком (коме „бог и срећа јуначка вољадне!”) 30 , тј. опет у вези с мотивом из уоквирене, епске приче. А у тој причи, разуме се, десетерци су опет чести: кад приликом калуђерског саветовања шта да се ради пред најездом Крајишника Симеун прекори Исаију што је предложио да се аустријска војска зове у помоћ: „Тешко оном кога други брани!”31. А и то саветовање се мора, наравно, заливати: „Пите браћо и Србови моји!”32; а поред тога ту ћемо чути још и правог гуслара који ће да нам одгуди неколико десетераца о јунаштву Парте игумана и Симеуна Ђака. Па и кад противник наиђе, у срцу наших јунака пропламсаће захвалност народу „који ће нас тако спомињати”з3. После још понеког десетерца, позива у бој („за мном ко се часним крстом крсти”) $)^{34}$, противничког изазивања: „Курво кучко, Симеуне Ђаче”35, у Симеуновом опису властитог коња позната десетерачка слика снажног људског гласа биће пренесена у визију коњског фрактања: „са дрвећа полијеће лишће”з6. Међутим, у даљем току епске приче, у сликама Симеуновог тријумфа над Асан-бегом Чеком, кога ће он натерати да узјахује свог коња и сјахује са њега док му срце не препукне, опет је антиклимакс потпуно епски огољен.

И у приповетки Ракијо, мајко! срце окршаја, призор у коме је аустријски капетан најзад присиљен да потпише калуђерима „бурунтију” да могу кренути у народ и скупљати стоку за манастир, дат је у чистој

\footnotetext{
${ }^{28}$ Нав. дело, стр. 134.

${ }^{29}$ Нав. дело.

${ }_{30}$ Мејдан Симеуна Ђака, стр. 139.

${ }^{31}$ Нав. дело, стр. 141.

${ }^{32}$ Нав. дело, стр. 142.

${ }^{33}$ Нав. дело.

${ }^{34}$ Нав. дело, стр. 143.

${ }^{35}$ Нав. дело, стр. 145.

${ }^{36}$ Нав. дело, стр. 146.
} 
комичкој прози, као што, уосталом, ни у „ракијској”, оквирној причи нема десетераца (изузев кад је реч о манастиру Гомионици, „Немањића светој задужбини”, односно „Немањића задужбини светој”) ${ }^{37}$. Прва значајнија десетерачка алузија појављује се кад Симеун одбија аустријско одликовање и каже аустријском капетану да су „нишане” носили увек издајници своје вере и народа: „а ја то нит сам био ни ћу икада бити”" кад Симеун дочепа дурбин да види ко предводи војску која га је опколила у противничком табору, он ће се толико обрадовати кад угледа Партенију, да ће сместа његово казивање прећи у десетерац: „Турчин није, а Каурин није, већ је главом Парто калуђере... Не бој ми се, мио побратиме! Што си мрке оточио брке? Разведри се силни генерале, данас ћемо у крв загазити. Биће меса орлу и гаврану... Не бој ми се, мио побратиме, већ ми предај команду над војском, да ја будем војсци војсковођа"з9. И после још неколико десетераца у готово истом даху, очекивани сукоб између аустријских снага и Партенијине ордије која је кренула да спасава Симеуна изостаје, а прича се завршава тако што калуђери добијају тражену „бурунтију” од капетана и успешно скупљају стоку - у чему им је опет ракија од непроцењиве помоћи. С два-три безначајна изузетка ово срце радње и расплет дати су опет у прози.

Наративна структура целог циклуса ових Кочићевих приповетки састоји се, дакле, од прозне и прозаичне оквирне приче о печењу ракије и уоквиреног, епски понесеног казивања у коме је присутност стандардних обележја нашег усменог епског песништва неупоредиво наглашенија. Међу тим обележјима, поред описа припрема за окршај, описа одеће, оружја и коња, поред похода, окршаја и рсплета, јавља се и низ других елемената нашег усменог епског песништва - обично у пародијској функцији. Тако се, рецимо, причешћивање војске уочи битке, познато из косовских песама као и из византијског војног протокола, суптилно пародира уочи Симеуновог пресретања Асан-бега Чеке: Партенија исповеда и причешћује једино Симеуна, док „осталу војску само благослови и пошкропи водицом" ${ }^{2}$. Сличног пародијског карактера је и призор гозбе у Зулуму Симеуна Ђака: прерушен у аустријског команданта, Симеун захтева у Мајдану да му се пред џамијом спреми „кесаџијски ручак: погача на копрен, печен крмак и десет ока вина" ${ }^{41}$. Па и средишња епска алузија

\footnotetext{
37 Ракијо, мајко!, стр. 150, 152.

${ }^{38}$ Нав. дело, стр. 158.

39 Нав. дело, стр. 162.

40 Мејдан Симеуна Бака, стр. 143.

41 Зулум Симеуна Бака, стр. 128.
} 
целог циклуса, алузија на „пошљедње вријеме”, на један од космичких концепата косовског разумевања историје, такође је пародијског карактера, јер не подразумева више природну и моралну почаст него време у коме „владике почеше коิ шикутори носити шкрљаке и шајцати се по чаршији у по бијела дана са швапским роспијама” ${ }^{2}$, време када ће „млоги главни људи и сви отачествени аркијереји, због масни' ајлука и царски' бурунтија” постати „муртати и невјерници своје цркве и народа”ж3. У ширем смислу то је, дакако, оно време кад нестаје турског „крволочног и бијесног зулума”, кад долази аустријска „ледена слобода”, „суви зулум који ће гристи срце и душу, а сисати крв и потајно ломити измождене кости" 44 . Но сама природа Кочићевог језика и уметничког исказа је таква да сведочи и да је настало „пошљедње вријеме” и за јуначку епску поезију, јер она само још може да живи у пародијском трзању, у халуцинацији, и то искључиво, или бар превасходно, у сликама припрема за бој или окршај који заправо у епском смислу никад ни не долази. Као да фреквенција епских алузија у циклусу о Симеуну Ђаку сведочи да смо већ дубоко загазили у времена у којима је епском духу могућно још једино да халуцинира и чека неког свог Годоа.

Структура ових приповетки у којима се пародија непрестано креће према парадоксу, које нас стално наводе да пожелимо да им поверујемо више него што је могуће, омогућује језику да обави посао идеја и порука. У културолошком смислу оне свакако садрже и низ одговора на питања која сукоб старих епских традиција, као облик живота, и нове цивилизације на Кочићевом Змијању једва да је могао у његово време и поставити. Реч је овде, дакако, ако не већ о немогућности да човек опстане као људско биће у цивилизацији, а оно бар о страховитом сужавању моралних избора и усахнућу моралне природе људских одлука и акција. Можда је за Симеуна епски свет дрога - његова булажњења доиста имају нешто од лепоте дрогираних снова и њихових халуцинација о кумуникацији. Али Симеуново надахнуће ипак није дрога, па чак ни само ракија, него и жива културна традиција усмене речи, и то управо у тренутку кад она губи шансу опстанка. Зато у комедији Симеуновог гласа има и трагичког треперења које преобличава пародичну визију у парадокс: за разлику од Кочићевих говора и понеког манифестационог записа, овде писац доиста нема шта да нам каже. У његовом рукаву нема ни марама ни мишева који прете да буду извађени: он само супротставља раскош свог

\footnotetext{
42 Мејдан Симеуна Ђака, стр. 139.

43 Ракијо, мајко!, стр. 157.

44 Нав. дело, стр. 165.
} 
историјског осећања и уметничког језика трагичном свету у коме се ни ракија више језиком не градира. Јер ако би Симеун у својим ракијским заносима можда и имао понешто да нам каже у шта би било красно поверовати, наративна и асоцијациона структура Кочићевог уметничког језика пребогата је да би могла делити такве заблуде или „истине”. Она је чисто величање заноса у свету у коме човек више нема - ако је икада и имао - чиме да се заноси. Јер „кад човек мисли, богови се смеју”, као што рече Кундера. Али кад се човек насмеје, можда би понекад и богови имали разлога да се замисле. 